\title{
THE FACTOR ANALYSIS THAT INFLUENCE THE STUDENT PURCHASE INTENTION IN SHOPEE E- COMMERCE
}

\author{
Vivi Iswanti Nursyirwan, Sasmita Sari Ardaninggar \\ Universitas Pamulang \\ dosen02226@unpam.ac.id
}

\begin{abstract}
The purpose of this research was to analyze the effect of Promotion, Website Quality and Trust on Purchase Intention in Shopee's e-commerce. The study employed purposive sampling with certain criteria and iteration formulas so that the number of samples obtained was 100 samples of Shopee e-commerce users from undergraduate students of The Economic Faculty of Pamulang University as respondents. By using Structural Equation Modeling with Partial Least Square Approach, the results indicated: (1) the promotion had positive and significant on purchase intention; (2) promotion had positive and significant on consumer's trust; (3) The results showed that between variables there was no significant influence between consumer's trust and purchase intention; (4 and 5) Website quality had a positive and significant influence on both purchase intention and consumer's trust. However, (6 and 7) Both the promotion and website quality had no significant influence to purchase intention with consumer's trust as intervening.
\end{abstract}

Keywords: Promotion, Website Quality, Trust, e-Commerce

\section{INTRODUCTION}

E-commerce described as a place for buyer and seller exchanging the product, service, information and money. In Indonesia, it grows rapidly and can even be said to be the fastest in the world by recording a growth of $78 \%$ in 2018 . According to the data from the Central Statistics Agency (BPS) in the past tenyears the number of e-commerce businesses has reached 26.2 million and will grow continously along with the growth in the number of Micro Small Medium Enterprises (UMKM). In addition, the lifestyle changes of Indonesian who want everything to be fast and easy has encouraged the growth of e-commerce. Shopee, Tokopedia and Bukalapak are three of the many ecommerce that have growth fastly in Indonesia.

The map e-commerce data released by www.iprice.co.id that Shopee managed to maintain her first position as top e-commerce for ten consecutives based on ranking in the Playstore and also led the Appstore ranking category. Shopee is an e-commerce with an orange icon from Singapore, founded by Forrest $\mathrm{Li}$ in 2009. Shopee has existed in various countries such as Singapore, Malaysia, 
Thailand, Taiwan, Indonesia, Philippines, Vietnam and Brazil. It Started entering Indonesian market in December 2015. Shopee is known to be able to provide free shipping services for consumers. It even begun to be followed by other e-commerce.

On the other hand, the growth of ecommerce has given a negative impact on the offline market in Indonesia. For instance, Hero Supermarket has closed 32 outlets during 2018 after closing 26 outlets previously. Over the past four years Hero has lost 165 of its stores in 2018. Matahari must also close its stores, which are 80 outlets within two years since 2016 (katadata,2018). The trading world has entered the new dimension ever since the emergence of e-commerce, especially for customer to customer (C2C) group. The teenagers become a group of consumers who active in using e-commerce. One of the example is the undergraduate students of Accounting Major of Pamulang University which has the second largest number of the students after Management Major (Kemendikbud, 2019). They prefer shopping through online market rather than offline market. It shows there is a changes of consumer's purchase intention. Purchase intention is defined as the behavior that arises as a response to an object and shows the desire to make a purchase (Kotler 2005:15). It is influenced by internal and external factors such as Indonesians used to like visiting offline market for shopping due to safety and trust reason. The other reason, they tend to see and touch the products before buying. Furthermore, there was a small number of internet users. Nowdays, they prefer to go online market due to ease, and simple reason.

Pavlou (2003), online purchase intention can be defined as a situation where a consumer is willing and intends to make online transactions.. Every consumer has different level of trust depend on the shopping experience they have (Liu, Dion dan Murphy, 2002). It is part of the consumer psychology attribution formed due to past experience and their environment (Mayer et al, 1995).

Consumer's trust and purchase intention may be affected by website quality and promotion. Websites that able to present comprehensive information about sellers and their products, can be regarded as quality website. Consumer perception of website quality is based on features that can meet the consumer needs (Mona et al., 2013). Website quality has various dimensions which categorized as security, enjoyment, information quality, ease of use, service quality and web design. According to Gregg dan Walczak (2010), consumer's trust that come from the website quality can increase the possibility to do transaction. It was supported by the research constructed by Shahnaz (2016) that there was a positive and significant influence between website quality and purchase intention with consumer's trust as intervening. Hasanov and Khalid (2015) said that website quality had indirect impact on online purchase intention especially for healthy food in Malaysia.

Promotion is thought to be a supporting factor that can increase consumer's trust and direct purchase intention. Based on the presentation above, the writers want to do a research with the title "THE FACTOR ANALYSIS THAT INFLUENCE THE STUDENT PURCHASE INTENTION IN SHOPEE ECOMMERCE"

\section{LITERATURE REVIEW}

\subsection{Theory Planned Behaviour}

Theory planned behavior by Ajzen (1991) describes that individual 
EAJ (Economics and Accounting Journal) - Vol. 3, No. 2, May 2020 - Nursyirwan \& Ardaninggar

targets have a high possibility of adopting a behavior if the individual has a positive attitude toward the behavior. Individual behavior can be also influenced the behavior intention (Sumarwan, 2011). The behavior intention is affected by three factors, that is behavioral belief, normative belief and control belief. The first factor is belief in the result of behavior and evaluation on it (Hidayat, 2019). Then, it will create the variable attitude towards that behavior. Normative is an individual belief on the normative expectations of others the reference, and it will create the variable subjective norm on behavior. The control is the individual belief on support and the power his/her perception on behavior. Theory planned behaviour has two important fitures, such as:

1. Perceived behavioral control has motivational implications for interest

People who believe that they do not have the opportunities to engage in certain behaviors may not form a strong interest to do it. Thus, there will be a correlation between perceived behavior control and intention without attitude and subjective norm.

2. The possible direct relationship between perceived behavioral control and behavior. The performance of behavior depends on the motivation and behavior control as well. Perceived behavior control can influence the behavior indirectly through interest, and predict behavior directly.

\subsection{Purchase Intention}

Purchase intention is defined as the basis for predicting the consumer behaviour before making a purchase of product(Kotler 2005:15). Consumer interest can predict the possibility to buy the product and convert to another brand (Keller, 2007).

Ferdinand (2009) had classified the indicator of purchase intention, such as:

1. Transactional intention, is the tendency to buy a product

2. Referential intention, is the tendency to promote the product to other

3. Prefenrential intention, is a description of behavior when consumers have a primary preference of the product. It can be replaced if something happens with their preference

4. Explorative intention, is the tendency to look for product information to support positive aspects of the products.

\section{Promotion}

Promotion is one of the important aspects for the companies to introduce their products or services to public. Not only as a communication tool between companies and consumers, but also as a tool to influence consumers for purchasing the products or services (Rambat Lupiyoadi, 2006).

According to Kotler and Armstrong (2008), Promotion is a specific guide to do advertising, sales promotion, public relations, personal selling, and direct marketing that use for communicating and creating relationships with customer. Kotler dan Keller (2012) divided the promotional mix into five groups, such as:

1. Advertising, is all the expenses that must be incurred to make nonpersonal presentations and promotions in the form of ideas, goods or services

2. Personal selling, is a personal presentations by salesperson in order to make sales successfully and build relationships with customers. 
EAJ (Economics and Accounting Journal) - Vol. 3, No. 2, May 2020 - Nursyirwan \& Ardaninggar

3. Sales promotion, is a short-term incentives to encourage the transaction

4. Public relation, is creating a good relationship with the public to build a corporate image and handle all the bad things happened with the company.

5. Direct marketing, is a direct communication with target customers to get immediate responses.

\section{Website Quality}

Buttner and Goritz (2008) explained that website is an important component in e-commerce because the consumer has the difficulty to see the product directly. Website has an ability to convey all the information to establish consumer's trust. Website quality formed by the perception of end user. It could be seen as an attribute that contributed to the user (Gregg dan Walczak, 2010)

Kim and Niehm (2009) revealed that the previous researcher had divided the dimension of quality website into five, such as:

1. Information (content quality, usability, completeness, accuracy and relevance)

2. Security (trust, privacy and security guarantees)

3. Easiness (easy to operate, easy to understand, and speed)
4. Convenience (visual appeal, emotional appeal, creative and attractive design)

5. Service quality (completeness on both online and customer service)

\section{Consumer's Trust}

Kwek et al. (2010) in his research "The Effects of Shopping Orientations, Online Trust and Prior Online Purchase Experience toward Customer's Online Purchase Intention" found that the consumer's trust had a positive and significant impact to purchase intention.

Koufaris dan Hampton-Sosa in Gregg dan Walczak (2010) stated that trust plays a very important role whenever two parties are involved in online transactions. Mayer et al (1995) classified three component of consumer's trust, such as:

1. Ability, is trust in the seller ability to fulfill consumer needs.

2. Integrity, is the trust level of seller's honesty on keeping up with their promises.

3. Benevolence, is the trust level of seller's honesty on doing wellbehave and giving good services.

Herewith the conceptual framework of this study as showns on Picture 1.

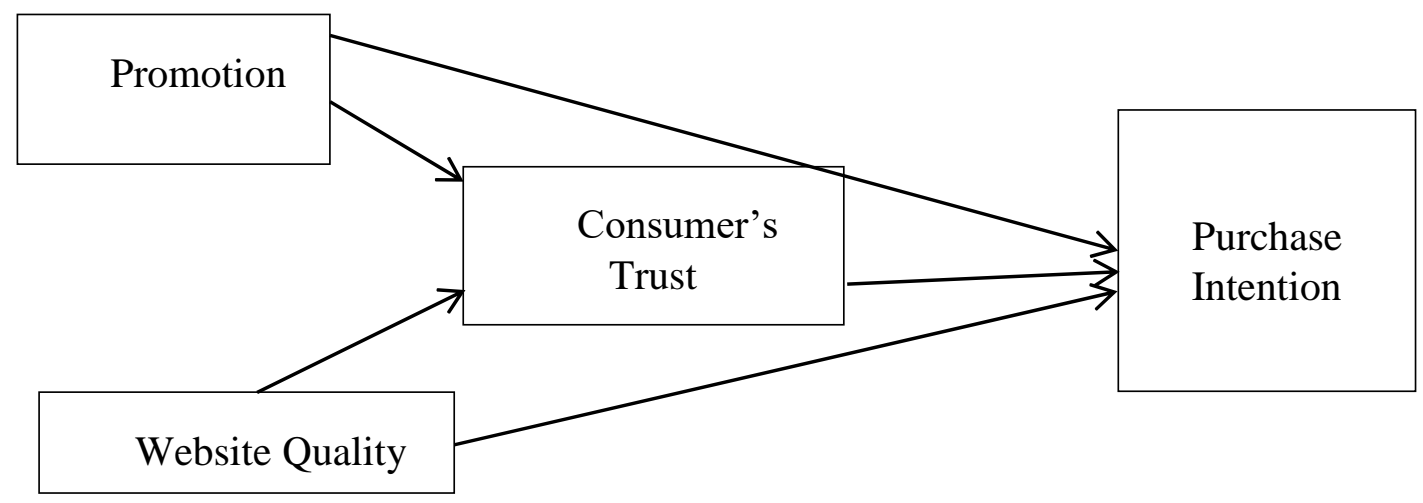

* Corresponding author's e-mail: dosen02226@unpam.ac.id http://openjournal.unpam.ac.id/index.php/EAJ 
EAJ (Economics and Accounting Journal) - Vol. 3, No. 2, May 2020 - Nursyirwan \& Ardaninggar

Picture 1. Conceptual Framework

\section{Hypothesis Development \\ Promotion}

The results study by Leonardus Himawan and Dibia Abduh (2015) stated that promotion had a significant effecton buying interest in online trading sites

H1: The effect of promotion to purchase intention will be positive and significant

Based on May, et al (2015), "The Privacy DYAD Antacendents of promotion and prevention focused online privacy behaviors and the mediating role of trust and privacy concern", it was concluded that trust is influenced by the company's reputation and the quality of its communication which described as promotion.

H2: The effect of promotion to consumer's trust will be positive and significant

\section{Website Quality}

Based on the findings by Chen et al. (2010) the user-friendly interface and ease of use have significant impact on online purchase intention for Taiwanese Internet users.

H3: Website quality has positive and significant influence on purchase intention

The quality of a website can increase the confidence of consumers who make transactions online (Pratiwi, 2012). Siagian and Cahyono (2014) stated that the quality of website affects on consumer's trust

H4: Website quality has positive and significant influence on consumer's trust

In the study entitled ,"A Trust based consumer decision making model in electronic commerce: The role of trust, perceived risk, and their antecedents", trust has a positive effect on buying interest because it will provide comfort to consumers when making transactions (Kim et al, 2007)

H5: Consumer's trust is significant and has positive impact on purchase intention

Pratama (2017) expressed that there wa a posistif effect on promotion and security on purchase intention as intervening variable.

H6: There is a significant impact between promotion and purchase intention with consumer's trust as intervening

Based on research by Shahnaz, NBF and Wahyono (2016), the quality of website had the positive and significant effect on purchase intention through trust as intervening variabel

H7: There is a significant impact between website quality and purchase intention with consumer's trust as intervening

\section{RESEARCH METHOD}

The study employed explanatory research which explain the cause-effect correlation between variables (independent and dependent) through hypothesis test.

\subsection{Data Collection Techniques}

The population in this study was 90.7 million Shopee users in 2019 (katadata, 2019). The sampling method used in this study is non probability sampling, where each member of the population has a zero value (Hidayat \& Sadewa, 2020). The 
EAJ (Economics and Accounting Journal) - Vol. 3, No. 2, May 2020 - Nursyirwan \& Ardaninggar

characteristics chosen from the undergraduate students of Acoounting Major of Pamulang University are the students who have made a minimum of one-time online buying at Shopee ecommerce By using Slovin formula, the samples with an error rate of $10 \%$ would be determined :

$$
\begin{gathered}
n=\frac{N}{1+N(k)^{2}}=\frac{90,7 \times 10^{6}}{1+90,7 \times 10^{6}(10 \%)^{2}} \\
=99.99988975 \approx 100 \\
\text { n means sample total }
\end{gathered}
$$

\subsection{Operational Definitions of Variables \\ Independent variables $\left(\mathbf{X}_{1}\right)$} Promotion, is a specific guide for advertising, sales promotion, community relations, personal selling, and direct marketing tools that companies use for communicating customer value and build customer relationship persuasively. (Kotler dan Armstrong, 2008). Kotler and Keller (2012) mentioned that there were five variable of promotional mix, such as:

1. Advertising

2. Personal Selling

3. Sales Promotion

4. Public Relation

5. Direct Marketing

Independent variables $\left(\mathrm{X}_{2}\right)$ Website Quality, can be seen as an attribute of a website that contributes to fulfill consumer needs (Gregg dan Walczak, 2010). Kim dan Niehm (2009) divided the dimension of website quality into five categories, such as:

1. Information

2. Security

3. Easiness

4. Convenience

5. Service Quality

Intervening variables

Consumer's Trust, is defined as the customer's expectation that a service provider can be relied upon to fulfill his promises. (Siagian dan Cahyono, 2014). Mayer et al (1995) classified the trust perception of online transaction into three components, such as:
1. Ability
2. Integrity
3. Benevolence

\section{Dependent variable (Z) Purchase Intention}

Ferdinand (2009) identified the indicators of purchase intention, such as:

1. Transactional intention

2. Referential intentiom

3. Preferential intention

4. Explorative intention

\subsection{Sample Collection Techniques}

Data obtained by distributing questionnaires online. The sampling technique used in this study was purposive sampling, which is the sampling technique with certain criterias (Sugiyono,2009). The Sample criteria in this study were students of the Faculty of Economics, Pamulang University who had shopped at least once in Shopee Ecommerce. By using Slovin formula, the samples with an error rate of $10 \%$ would be determined.

$$
\begin{gathered}
n=\frac{N}{1+N(k)^{2}} \\
=\frac{90,7 \times 10^{6}}{1+90,7 \times 10^{6}(10 \%)^{2}} \\
=99.99988975 \approx 100 \\
\text { n means sample total } \\
\mathrm{N} \text { means population total }(90.7 \\
\text { million of Shopee users in Indonesia by }
\end{gathered}
$$
2019)

$\mathrm{K}$ means error level (10\%).

\subsection{Data Analysis Techniques}


EAJ (Economics and Accounting Journal) - Vol. 3, No. 2, May 2020 - Nursyirwan \& Ardaninggar

. The data analysis method used in this study was outer model, consist of convergent validity and reliability, then inner model and hypothesis test. Moreover, it would apply Structural Equation Modelling with Partial Least Square approach.

\section{RESULTS AND DISCUSSION 4.1 Results}

This study applied the Smart PLS application version 3.1.6 for data processing to create the model, loading factor, significance level on each latent variable.

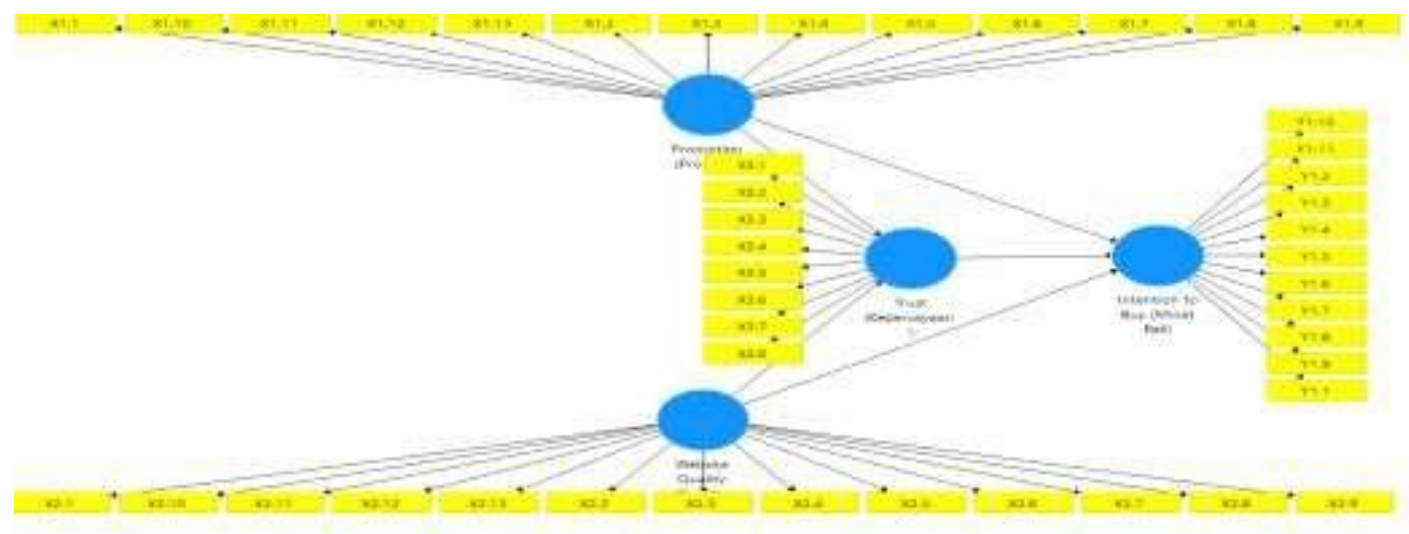

\section{Picture 2 Preliminary Research Model}

\section{Running SEM-PLS}

On the preliminary test, the loading score was still under the requirement of validity 0.70 (X1.13 and Y1.10) so that the score must be removed to increase the validity and reliability.

According to Average Variance Extracte (AVE) results, Endogenous latent variable (purchase intention) had 0.681 AVE while exogenous variables, (promotion and website quality) had a 0.642 and 0.764 AVE. Intervening variable (consumer's trust had 0.855 AVE. It meant all variables were valid

\section{Structural Model (Inner Model)}

Table below showed that the adjusted $\mathrm{R}$ squares were 0.818 for purchase intention and 0.858 for consumer's trust. It meant the research model was strong because The value of AVE were more than 0.50 .

\section{Reliability Test}

The construct will be reliable if the value of Cronbach's Alpha and Composite Reliability is above 0.70 . According to the result of Cronbach's Alpha and Composite Reliability all the construct had score more than 0.70 . it meant the consistency and stability were high. Thus, the construct or variable in this study become fit and the questionnaire had reliable questions. It meant each construct had a good level of reliability.

(Hair in Latan dan Ghozali,2012). Both purchase intention and consumer's trust had 0.514 and 0.680 positive $\mathrm{Q}^{2}$. If $\mathrm{Q}^{2}>$ 0 , it meant the model research has predictive relevance. 
EAJ (Economics and Accounting Journal) - Vol. 3, No. 2, May 2020 - Nursyirwan \& Ardaninggar

\begin{tabular}{l|cc}
\hline Variabel & R Square Adjusted & $\boldsymbol{Q}^{\mathbf{2}}$ predictive relevance \\
\hline Purchase Intention & 0.818 & 0.514 \\
\hline Consumer's Trust & 0.858 & 0.680 \\
\hline
\end{tabular}

Tabel 1. $R$ Square dan $Q^{2}$ predictive relevance

The Hypothesis test can be done by looking at the value of the path coefficient which shows the parameter coefficient and the t-statistic value. The Estimated of significant parameter provides information about the relationship between the variables then

comparing the t-statistic value with the $\mathrm{t}$ table value

If $\mathrm{t}$-statistic is higher than $\mathrm{t}$-table, it means hypothesis is accepted. This study applied the siginificance level $\alpha$ for $10 \%$, so that the t-table was 1.64

Table 2: Path Coefficient

\begin{tabular}{|c|c|c|c|c|c|}
\hline Variabel & $\begin{array}{l}\text { Original } \\
\text { Sample }\end{array}$ & $\begin{array}{l}\text { Sample } \\
\text { Mean }\end{array}$ & $\begin{array}{l}\text { Standard } \\
\text { Error }\end{array}$ & $\begin{array}{l}\text { T } \\
\text { Statistics }\end{array}$ & $\begin{array}{l}\mathbf{P} \\
\text { Values }\end{array}$ \\
\hline Promotion--> Purchase Intention & 0.333 & 0.361 & 0.117 & 2.854 & 0.005 \\
\hline Promotion-->Consumer's Trust & 0.199 & 0.217 & 0.096 & 2.066 & 0.039 \\
\hline Website Quality--> Purchase Intention & 0.431 & 0.404 & 0.164 & 2.634 & 0.009 \\
\hline Website Quality--> Consumer's Trust & 0.749 & 0.730 & 0.095 & 7.859 & 0.000 \\
\hline $\begin{array}{l}\text { Consumer's } \\
\text { Intention }\end{array}$ & 0.179 & 0.176 & 0.139 & 1.288 & 0.198 \\
\hline $\begin{array}{l}\text { Promotion--> Purchase Intention (with } \\
\text { Consumer's Trust as Intervening } \\
\text { Variable) }\end{array}$ & 0.036 & 0.035 & 0.034 & 1.061 & 0.289 \\
\hline $\begin{array}{l}\text { Website Quality--> Purchase Intention } \\
\text { (with Consumer's Trust as Intervening } \\
\text { Variable) }\end{array}$ & 0.134 & 0.136 & 0.110 & 1.220 & 0.223 \\
\hline
\end{tabular}

\subsection{Discussion}

\section{Discussion of Hypotheses :}

The Effect of Promotion to Purchase Intention

The path coefficient between promotion and purchase intention was 0.333 with t-statistic $2.854>1.64$ (significance level $\alpha=0.1$ ), which meant there was a positive and significant impact between promotion and purchase intention. The higher level of promotion, will lead the increasing on purchase intention. In the other words, $\mathrm{H}_{1}$ being accepted. The result supported by Leonardus Himawan dan Dibia Abduh (2015) explained the promotion significantly influenced the purchase intention. It shows the promotional activities carried out by the Shopee ecommerce affect on the student's purchase intention.

The Effect of Promotion to Consumer's Trust

The path coefficient between promotion and consumer's trust was 0.199 with nilai t-statistic $2.066>1.64$ (significance level $\alpha=0.1$ ), which meant there was a positive and significant impact between promotion and consumer's trust. The higher level of 
EAJ (Economics and Accounting Journal) - Vol. 3, No. 2, May 2020 - Nursyirwan \& Ardaninggar

promotion, will lead the increasing on consumer's trust. In the other words, $\mathrm{H}_{2}$ being accepted. The result is in line with May et al (2015), the promotion has a positive and significant influence on trust. It illustrates the promotional activities undertaken by Shopee ecommerce affect on student trust in Shopee e-commerce

\section{The Effect of Website Quality to Purchase Intention}

The path coefficient between website quality and purchase intention was 0.431 with t-statistic $2.634>1.64$ (significance level $\alpha=0.1$ ), which meant there was a positive and significant impact between website quality and purchase intention. The higher level of website quality, will lead the increasing on purchase intention. In the other words, $\mathrm{H}_{3}$ being accepted. The result supported by Mohd Fazli et al (2009); Nor Azuren Rozekhi et al (2014), the quality of website information has a significant effect on purchase. It describes the quality of the Shopee ecommerce website has a positive and significant effect on students' buying interest.

\section{The Effect of Website Quality to Consumer's Trust}

The path coefficient between website quality and consumer's trust was 0.749 with t-statistic $7.859>1.64$ (significance level $\alpha=0.1$ ), which meant there was a positive and significant impact between website quality and consumer's trust. The higher level of website quality, will lead the increasing on consumer's trust. In the other words, $\mathrm{H}_{4}$ being accepted. The result supported Siagian \& Cahyono (2014), the website quality has signifivant influence on trust. It means the consumer trust on Shopee ecommerce due to the quality of website.

\section{The Effect of Consumer's Trust to Purchase Intention}

The path coefficient between consumer's trust and purchase intention was 0.179 with t-statistic $1.288<1.64$ (significance level $\alpha=0.1$ ), which meant there was no significant effect between consumer's trust and purchase intention. In the other words, $\mathrm{H}_{5}$ being rejected.The result study shows there is not a significant influence between consumer's trust and purchase intention and supported by Harris\&Goode (2010). Moreover, Mona Afshardost et al (2013) explained the consumer's trust has a negative effect on purchase intention.

The Effect of Promotion to Purchase Intention with Consumer's Trust as Intervening

The path coefficient between promotion and purchase intention was 0.036 with t-statistic $1.061<1.64$ on (significance level $\alpha=0.1$ ), which meant there was no significant effect between promotion and purchase intention with consumer's trust as intervening. In the other words, $\mathrm{H}_{6}$ being rejected. The results of it differ from Pratama (2017) which described that promotion and security influence simultaneously purchase intention with trust as an intervening

\section{The Effect of Website Quality to Purchase Intention with Consumer's Trust as Intervening}

The path coefficient between website quality and purchase intention was 0.134 with t-statistic $1.22<1.64$ (significance level $\alpha=0.1$ ), which meant there was no significant effect between website quality and purchase intention with consumer's trust as intervening. In the other words, $\mathrm{H}_{7}$ being rejected. It differs from the research of Ganguly et al (2010) which stated that website quality influences 
EAJ (Economics and Accounting Journal) - Vol. 3, No. 2, May 2020 - Nursyirwan \& Ardaninggar

buying interest with trust as an intervening variable.

\section{CONCLUSION}

The conclusions of this study based on data analysis and research discussion were as follows:

1. The promotion variable influences purchase intention. $\mathrm{H}_{1}$ accepted.

2. The promotion variable influences the consumer's trust. $\mathrm{H}_{2}$ accepted.

3. The quality of website affects purchase intention. $\mathrm{H}_{3}$ accepted.

4. The quality of website affects consumer's trust. $\mathrm{H}_{4}$ accepted.

\section{REFERENCES}

Afshardost, M., Farahmandian, S. dan Sadiq E. 2013."Linking Trust, Perceived Website Quality, Privacy Protection, Gender and Online Purchase Intentions".IOSR Journal of Business and Management, 13(4)

Ajzen, I. (1991). The Theory of Planned Behavior. Organizational Behavior and Human decision Processes,50, 179-211. doi: 10.1016/07495978(91)90020-T

Büttner, O. B., \& Göritz, A. S. (2008). Perceived trustworthiness of online shops. Journal of Consumer Behaviour: An International Research Review, 7(1), 35-50.

Chen, Y.H., I. Hsu, \& C.C. Lin, 2010. 'Website attributes that increase consumer purchase intention: A conjoint analysis, Journal of Business Research, 63(9): 1007-14. Ganguly, B., Dash, S. B., Cyr, D., \&
5. There is no effect on consumer's trust and purchase intention. $\mathrm{H}_{5}$ rejected.

6. There is no effect on the promotion to purchase intention with consumer's trust as intervening variable. $\mathrm{H}_{6}$ rejected.

7. There is no effect on the quality of website to purchase intention with consumer's trust as intervening variable. $\mathrm{H}_{7}$ rejected.

Head, M. (2010). The effects of Website Design on Purchase Intention in Online Shopping : The Mediating Role of Trust and The Moderating Role of Culture. International Journal Electronic Business, 8, 302-330.

Gregg, D. G., \& Walczak, S. (2010). The relationship between website quality, trust and price premiums at online auctions. Electronic Commerce Research, 10(1), 1-25.

Hasanov, J. And Khalid (2015). The Impact of Website Quality on Online Purchase Intention of Organic Food in Malaysia: A Webqual Model Approach. Elsevier. Procedia Computer Science 72, 382-389

Hidayat, A. (2019). Student's SelfConcept Profiles in Problem Posing According to Cognitive Styles: 
EAJ (Economics and Accounting Journal) - Vol. 3, No. 2, May 2020 - Nursyirwan \& Ardaninggar

Developing An Evidence Base for Best Practice of E-Learning in Mathematical Economics Course at Pamulang University. Jurnal Saintika Unpam: Jurnal Sains dan Matematika Unpam, 1(2), 158165.

Hidayat, A., \& Sadewa, P. (2020). Pengaruh Penggunaan Aplikasi Eviews Terhadap Sikap Belajar dan Kemampuan Pemecahan Masalah Statistik. Edumaspul: Jurnal Pendidikan, 4(1), 321-328.

Himawan,LeonardusdanAbduh,Dibia.20 15.AnalysisofOnlineSalesPromoti onTowardYouthPurchaseIntentioni nIndonesia(CaseStudyofApparelInd ustry).Ijaber, 13(7)

Idris, AW. 2018.PENGARUH PROMOSI,

KEMUDAHANPENGGUNAAN, KEPERCAYAAN KONSUMEN DAN KUALITAS INFORMASI TERHADAPMINAT BELI DI SITUS

BUKALAPAK(PadaMahasiswaUni versitasDiponegoro).

DIPONEGORO JOURNAL OF MANAGEMENT. Volume (7): 1-6

Jiang,Yuanchun.,Shang,Jennifer.,Liu,Ye zheng dan

May,Jerold.(2015), Redesaigning promotion strategy for e-commerce competitiveness through pricing and recommendation. Journal of Information Production Economics, 167, 257-270

Kemendikbud (2019). Website [Online].https://pddikti.kemdikbud .go.id/data_pt/MkU2MjlCMTUtOT BCMC00MDAxLTk1RDAtMDI2 QTMwQzhEODE0 [diakses pada 14 juni 2020 pukul 15.30].

Katadata (2019). Website [Online]. https://databoks.katadata.co.id/data publish/2019/09/03/shopee-jadi-ecommerce-paling-top-dari-masake-masa. [diakses pada 14 juni 2020 pukul 15.00].

Kim,Dan J.,Ferrin,Donald L dan Rao,H Roghav.(2007).”A trust-based consumer decision-making model in electronic commerce: the role of trust, perceived risk, and their antecedents".Decision Support System, No.44.pp. 544-564

Kim, H., \& Niehm, L. S. (2009). The impact of website quality on information quality, value, and loyalty intentions in apparel retailing. Journal of interactive marketing, 23(3), 221-233.

Kotler, et al. (2007).Manajemen Pemasaran, Jilid I, Edisi Kedua belas, PT. Indeks, Jakarta.

Kotler, P. (2005). Manajemen Pemasaran Edisi kesebelas Jilid 2, Indeks, Jakarta.

Kotler, P. \& Armstrong, G. (2008). Prinsip-prinsip Pemasaran. Edisi12. Jilid 1. Jakarta: Erlangga.

Kotler, P. \& Keller (2012). Manajemen Pemasaran. Edisi 12. Jakarta: Erlangga.

Lloyd C. Harris, \& Goode, M. M. H. (2010). Online servicescapes, trust , and purchase intentions. Journal of Service Marketing, 24(3), 230-243. http://doi.org/10.1108/0887604101 1040631

Latan, H \& Ghozali, I. (2012). Partial Least Squares: Konsep, Teknik dan Aplikasi Menggunakan Program SmartPLS 2.0 M3, Badan Penerbit Universitas Diponegoro, Semarang. Ling, K. C., Chai, L. T., \& Piew, T. H. (2010). The effects of shopping orientations, online trust and prior online purchase experience toward customers' online purchase intention. International business research, 3(3), 63.

Marketers (2011). Website. [Online] http://themarketeers.com/archives/s urvey-markplus-insightmajalahmarketeers-penggunainternet-di-indonesia-55-jutapenggunamobile-internet-29juta.html [diakses pada 29 November 2019]

Mayer, R. C., Davis, J. H., \& Schoorman, 
EAJ (Economics and Accounting Journal) - Vol. 3, No. 2, May 2020 - Nursyirwan \& Ardaninggar

F. D. (1995). An integrative model of organizational trust. Academy of management review, 20(3), 709734.

Mujiyana, M., \& Elissa, I. (2013). Analisis faktor-faktor yang mempengaruhi keputusan pembelian via internet pada toko online. J@ TI Undip: Jurnal Teknik Industri, 8(3), 143-152.

Pavlou, P.A (2003). Consumer acceptance of electronic commerce: Integrating trust and risk with the technology acceptance model. International Journal of Electronic Commerce, 7 (3), 197-226.

Pratama, RB dan Rizal Hari Magnadi. 2017. ANALISIS PENGARUH PROMOSI DAN PERSEPSI KEAMANAN TERHADAP KEPERCAYAAN SERTA IMPLIKASINYA TERHADAP MINAT BELI DI E-COMMERCE (Studi pada Pengguna blibli.com). DIPONEGORO JOURNAL OFMANAGEMENT. 6(3), 1-11

Pratiwi, H. D., Silviandari, I. A., \& Ilhamuddin. (2012). Pengaruh Reputasi Perusahaan dan Kualitas Website terhadap Tingkat Kepercayaan Konsumen (Studi pada Konsumen Ongisnadestore.com), 1-
23.

Rambat, L.\& A. Hamdani (2006). Manajemen Pemasaran Jasa. Edisi Kedua. Jakarta; Salemba Empat.

Shaheen Mansori, Cheng, Boon Liat,\&Lee, Hui Shan (2012). A Study of E-Shopping Intention in Malaysia : The Influence of generatiion $\mathrm{X}$ \& $\mathrm{Y}$. Australian Journal of Basic and Applied Aciences, 6 (8), 28-35.

Shahnaz, NBF dan Wahyono. (2016). FAKTOR YANG MEMPENGARUHI MINAT BELI KONSUMEN DI TOKO ONLINE. Management Analysis Journal

Siagian, H., \& Cahyono, E. (2014). Analisis website quality, trust dan loyalty pelanggan online shop. Jurnal Manajemen Pemasaran, $8(2), 55-61$.

Sugiyono. (2009). Metode Penelitian Kuantitatif, Kualitatif dan R\&D, Bandung : Alfabeta

Sumarwan, Ujang. 2011. Perilaku Konsumen Teori Dan Penerapnnya Dalam Pemasaran Edisi 2. Bogor : Graha

Susanti, V., Hadi, C., \& Si, M. (2013). Kepercayaan Konsumen dalam Melakukan Pembelian Gadget secara Online. Jurnal Psikologi Industri dan Organisasi, 2(01). 